\title{
A Lesson From Corona Virus Disease 2019: Exploring the Science in the Book of Signs
}

\author{
Muh. Naim Madjid ${ }^{1, *}$ \\ ${ }^{1}$ Department of Arabic education, Universitas Muhammadiyah Yogyakarta, Indonesia \\ * Email: naimmadjid@umy.ac.id
}

\begin{abstract}
Science and sign are two different words with a close relationship where they both have to be present to complete one another. COVID-19 has been declared by World Health Organization (WHO) in March 2020 as a pandemic with the global spread of a new disease since December 2019 and has successfully taken the world's attention in May 2020. The purpose of this paper is to disclosure the phenomenon of COVID-19 in exploring science in the book of signs, AlQur'an. Specifically, this paper will look into the diction of the Quran, leading to an important lesson that COVID19is a result of man's negligence towards himself. Humanity today is far from knowing nature (fitrah) of himself. This study is qualitative research based on the scientific facts, which used a descriptive analytical approach to the Quran's language as signs of knowledge and all events on this earth in the past, present, and future. The critical result showed that the phenomenon of COVID-19 was a scientific fact that could only be understood correctly by knowing the signs of the Quran as a source of knowledge reflected in its miracle of language and meaning.
\end{abstract}

Keywords: Lesson, Corona Virus Disease 2019, Science, Signs

\section{INTRODUCTION}

Corona virus disease is an infectious disease caused by a newly discovered corona virus. Corona virus disease pandemic is one of the worst health crises since the beginning of the 21st century. In less than six months (March to August 2020), the corona virus disease, known as COVID-19 has affected around 27 million people and the death toll exceeds 800,000 worldwide [1]. The infectious disease has put many countries on lockdown with the most potent health procedure to break the infection chain. The statistical data of coronavirus changes rapidly. In this global situation, WHO reported at 3:36pm CEST, September 9, 2020, 27.486.960 confirmed cases of COVID-19, including 894.983 deaths. Total counts do not include all locations because some areas may not have data and have not published their data or have not done so recently. Data of Confirmed Cases came from 7 months (March-Sepetember 2020), where since March 10, 2020, Confirmed Cases (CC) is around 4,476 with Daily Increase (DI) 499, strongly increased to $89,335 \mathrm{CC}$ and 3,484 of DI on April 11, 2020. The data fluctuated with a small increase to May 18 which reached 101,399 of
CC and 6,792 of DI, then it started to increase with high additions on August 15 with 297,391 of CC and 10,325 of DI, and reached the peak on September 6, 2020 in 307,121 of Confirmed Cases and 12,091 of Daily Increase.

According to the last WHO's data, the confirmed cases in America reached 14,257,006, South-East Asia reached 4,964,948, Europe was 4,600,967, Eastern Mediterranian was 2,040,265, while Africa was 1,096,731, and Western Pacific reached 526,302. Simultaneously, the highest tree cases are United States, India, and Brazil, with 6,248.989, 4,470.128, and 4,147.794 cases [2]. In 23rd place, Indonesia has reached $203 \mathrm{~K}$ Cases, consisting of $145 \mathrm{~K}$ recovered, and 8,336 deaths. The data were obtained from the last updated on September 9, 2020, 3.36pm CEST by World Health Organization (WHO) as on the following table: 


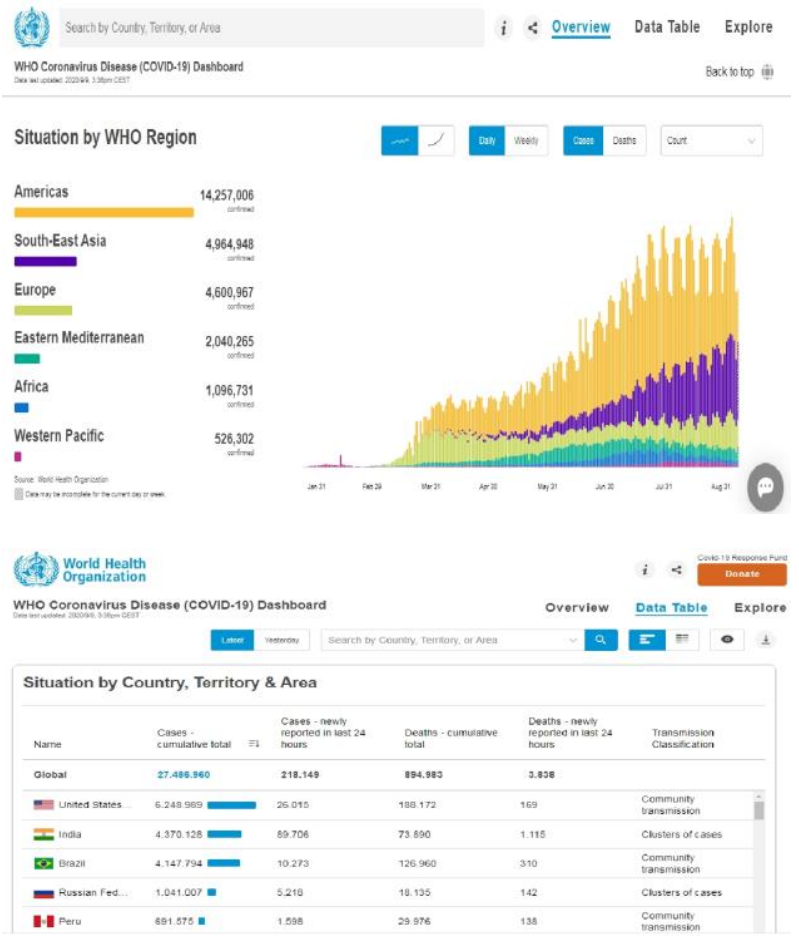

Source: World Health Organization

Most people infected with the COVID-19 virus will experience mild to moderate respiratory illness and recover without requiring special treatment. Older people, and those with underlying medical problems such as cardiovascular disease, diabetes, chronic respiratory disease, and cancer are more likely to develop severe illness [3].

In the critical preparedness, readiness and response actionsfor COVID-19, WHO has emphasized that all countries should increase their preparedness, alertand response to identify, manage, and care for new cases of COVID-19. Countries should prepare to respond to different public health scenarios, recognizing that there is no one-sizefits-all approach to managing cases and outbreaks of COVID19. Each country should assess its risk and rapidly implementthe necessary measures at the appropriate scale to reduce both COVID-19 transmission and economic, public and social impacts [4]

The best way to prevent and slow down transmission is to be well informed about the COVID-19 virus, the disease it causes and how it spreads. People should protect themselves from infection by washing their hands or using an alcohol-based rub frequently and not touching their face. The COVID-19 virus spreads primarily through droplets of saliva or discharge from the nose when an infected person coughs or sneezes, so it is essential to practice respiratory etiquette (for example, coughing into a flexed elbow) [3].

The most crucial matter is how people realize the importance of cleanliness for personal and public health and fully believe that all phenomena in this world are the Creator's willing whose information and explanations are mentioned through impressive signs in the Holy Qur'an. This point will be highlighted profoundly in the textual and contextual approaches.

\section{MEANING AND CONCEPT}

\subsection{Virus}

A virus is a submicroscopic infectious agent that replicates only inside an organism's living cells [5]. Viruses infect all life forms, from animals and plants to microorganisms, including bacteria and archaea [6]. Viruses are found in almost every ecosystem on Earth and are the most numerous type of biological entity [7]. The study of viruses is known as virology, a subspeciality of microbiology.

Viruses spread in many ways. One transmission pathway is through disease-bearing organisms known as vectors. Viruses are often transmitted from plant to plant by insects that feed on plant sap, such as aphids, and blood-sucking insects can carry viruses in animals. Influenza viruses are spread by coughing and sneezing. Norovirus and rotavirus, common causes of viral gastroenteritis, are transmitted by the fecal-oral route, passed by hand-to-mouth contact or in food or water. The infectious dose of norovirus required to produce infection in humans is less than 100 particles [8].

The word is from the Latin neuter vīrus referring to poison and other noxious liquids, from the same IndoEuropean base as Sanskrit vișa, Avestan vīša, and ancient Greek (all meaning "poison"), first attested in English in 1398 in John Trevisa's translation of Bartholomeus Anglicus's De Proprietatibus Rerum [9].

Viruses are found wherever there is life and have probably existed since living cells first evolved [10]. Viruses' origin is unclear because they do not form fossils, so molecular techniques investigate how they arose [11]. Also, viral genetic material occasionally integrates into the host organisms' germline, which they can be passed on vertically to the offspring of the host for many generations. It provides an invaluable source of information for paleovirologists to trace back ancient viruses that have existed up to millions of years ago. 
Three main hypotheses that aim to explain the origins of viruses: regressive hypothesis, cellular origin hypothesis, and co-evolution hypothesis.

In conclusion, viruses have different mechanisms by which they produce disease in an organism, which depends mostly on the viral species. Although viruses disrupt healthy homeostasis, resulting in disease, they may exist relatively harmlessly within an organism. An example would include the herpes simplex virus's ability, which causes cold sores, to remain in a dormant state within the human body.

\subsection{COVID-19 and Global Impact}

The COVID-19 pandemic, also known as the corona virus pandemic, is an ongoing pandemic of coronavirus disease 2019 (COVID-19) caused by severe acute respiratory syndrome corona virus 2 (SARS-CoV-2). It was first identified in December 2019 in Wuhan, China [1]. The World Health Organization declared the outbreak a Public Health Emergency of International Concern on January 30, 2020, and a pandemic on March 11. As of September 10, 2020, more than 27.8 million cases have been reported in more than 188 countries and territories, resulting in more than 904,000 deaths; more than 18.7 million people have recovered [12].

Symptoms of COVID-19 can be relatively nonspecific. The two most common symptoms are fever ( 88 percent) and dry cough (68 percent). Less common symptoms include fatigue, respiratory sputum production (phlegm), loss of the sense of smell, loss of taste, shortness of breath, muscle and joint pain, sore throat, headache, chills, vomiting, coughing out blood, diarrhea, and rash [13].

Strategies for preventing disease transmission include maintaining overall good personal hygiene, washing hands, avoiding touching the eyes, nose, or mouth with unwashed hands, coughing or sneezing into a tissue, and putting the tissue directly into a waste container. Those who may already have the infection have been advised to wear a surgical mask in public. Physical distancing measures are also recommended to prevent transmission. Health care providers taking care of someone who may be infected are recommended to use standard precautions, contact precautions, and eye protection.

The outbreak is a major destabilizing threat to the global economy. Hundreds of millions of jobs could be lost globally. The outbreak has been blamed for several supply shortages, stemming from globally increased equipment usage to fight outbreaks, panic buying and disruption to the factory and logistic operations. The spread of panic buying has been found to stem from a perceived threat, perceived scarcity, fear of the unknown, coping behavior and social psychological factors (e.g. social influence and trust). The performing arts and cultural heritage sectors have been profoundly affected by the pandemic, impacting organizations operations and individuals-both employed and independent - globally. The pandemic has affected the multiple countries' political systems, causing suspensions of legislative activities, isolations or deaths of multiple politicians, and rescheduling elections due to fears of spreading the virus.The measures taken to combat the pandemic are part of an unusually large expansion of government power. Advocates of small government worry that the state will be reluctant to give up that power once the crisis is over, as has often been the case [14]. Several famines are forecast caused by pandemic, alongside lockdowns and travel restrictions, which has prevented aid movement significantly impacted food production, which the United Nations called a "hunger pandemic" [15].

The pandemic has affected educational systems worldwide, leading to the near-total closures of schools, universities and colleges. School closures impact not only students, teachers, and families, but have farreaching economic and societal consequences. In response to the pandemic, school closures have shed light on various social and economic issues, including student debt, digital learning, food insecurity, homelessness, and access to childcare, health care, housing, internet, and disability services. The impact is more severe for disadvantaged children and their families, causing interrupted learning, compromised nutrition, childcare problems, and consequent economic cost to families who could not work. In response to school closures, UNESCO recommends the use of distance learning programs and open educational applications and platforms that schools and teachers can use to reach learners remotely and limit education disruption [16].

The pandemic has caused a global reduction in modern human activity, leading many regions to experience an extensive air pollution drop. Other positive impacts on the environment include governance-system-controlled investments towards a 
sustainable energy transition and other environmental protection goals.

The climax of the crisis caused by corona virus-19 is the moral crisis and belief in God. Since the start of the outbreak, heightened prejudice, xenophobia, and racism have been documented worldwide toward people of Chinese and East Asian descent [17]. Discrimination against Muslims in India has escalated after public health authorities identified an Islamic missionary (Tabligh Jama'at) group's gathering in New Delhi in early March 2020 as a source of spread. In China, some of the African descents were evicted from their homes by police and told to leave China within 24 hours, due to disinformation that they and other foreigners were spreading the virus.In social interaction, some people feel anxiety and avoid meeting, their family members from other cities or places during pandemics. These impacts have made human relationships more difficult, and the loss of belief in divine pre-decree.

\section{DISCLOSURE OF SIGNS IN THE HOLY QUR'AN ABOUT COVID-19}

Allah the Almighty tells in the Qur'an that lots of signs will be established to confirm that Islam is the truth. The scientific discoveries in this era are affirming what Allah has hinted. Muslims in the Qur'an more than 1400 years back. Allah saiys in the Surah Fussilat (They are explained in detail): 53: "We will show them Our Signs in the horizons and within themselves until it becomes clear to them that it is the truth. But is it not sufficient concerning your Lord that $\mathrm{He}$ is, over all things, a Witness?".

In principle, these signs are aimed at the people who reflect (yatafakkarun), for men of sound knowledge ('Alimin), for a people who listen (yasma'un), and for a people who understand (ya'qilun), and they may turn back (la'allahumyarji'un).

Charles Darwin's evolutionary science about natural selection suggests that, because resources are finite, and because of random variation, some individuals will be better than others at accessing those resources, and the idea of Tree of Life and what Bernard Wood said in his book that all species, including modern humans, will ultimately become extinct. The issue is whether extinctions are determined by species' intrinsic properties, or by extrinsic factors such as changes in the environment, or by a combination of the two [18]. These assumptions try to construct people's minds under the theory that human life is solely determined and affected by the environment, resources, signs and phenomena. Misunderstanding of signs will lead to misinterpretation and deviation.Islam views humans as Caliphs on earth. A perfect man does not depend solely on others by fighting, competing and hurting, but needs a harmonious, peaceful, and balanced social interactions in this temporary life towards real life in the hereafter. This statement is the accurate Islamic view (AlTashawwur al- Islami), responding to all prevailing conditions and phenomena.

The linkage of humans and coronavirus disease is not strictly the causality relation with the measurable external indicators such as healthy lifestyle, hand washing, wearing a face mask, andcovering mouth when coughing, but actually there is a close connection and more critical is between human life and God' test. The Lord of 'Alamin mentions in the Holy Qur'an: "And We will surely test you with something of fear and hunger and a loss of wealth and lives and fruits, but give good tidings to the patient" (Al- Baqarah: 155). He said in another verse: "And surely, We shal try you till We test those whos strive hard (for the cause of Allah) and AsSabirin (the patient), and We shall test your facts (i.e., the one who is a liar, and the one who is truthful) (Surah Muhammad: 31).

\section{SURAH AL-MUDDATHTHIR(THE ONE ENVELOPED) AND NUMBER 19}

The qur'anic expression is connected to the coronavirus disease since 2019, Bessam Djerrar- a contemporary Quran interpreter - in a scientific paper [19] mentions that Surah Al-Muddathir as the foundation of a better understanding ofmatters related to today's world. Djerrar's argument seems to be strong enough to claim the truthfulness of the idea that surah Al-Muddathir mentions COVID-19 in detail. This research paper suggests that the COVID-19 pandemic is treated in detail in the Surah Al-Muddathir. It can be divided into seven subsections; each is representing a stage of understanding COVID-19 [19]:

1. Verses 1-7, warning from an imminent threat, provide the anti-pandemic protective measures (sanitary prophylaxis): chiefly, cleanliness of clothing and avoidance of the factors compromising the immune system such as depression. The seventh verse, in particular, urges patience and repentance in hard times. 
2. Verses 8 \& 9 mention the pandemic news announcement by mass media and a global threat warning.

3. Verses 11-25 present the aetiology of COVID-19: God Almighty vows to inflict hardship and fatigue on those who have denied His blessings (health, wealth and good life); this seems the case today.

4. In Verses 26-31, the Arabic word "سقر" (Saqar) refersto the heat that hurts the brain. These verses have been interpreted by Ibn Kathir, a well-known interpreter of the meanings of the Quran, who wrote that Saqar would swamp him from all sides by order of God Almighty. This interpretation means catching hyperthermia, which is among the symptom of a COVID-19 positive case. Regarding the section that reads: 'over it is nineteen', it is worth noting that there is a controversy between early and contemporary Quran meaning interpreters, in those early scholars (Al-Baghawi) referring the number "19" to angels while contemporary scholars (Bessam Djarrar) have referred it to the number of introductory Arabic sentence بسم الله الرحمن الرحيم)(In the Name of Allah, the Most Merciful, the Most Gracious). Regarding verse 30 , it is also worth mentioning that it counts 12 letters, and, to us, this could be referring to December, when the first case was reported to contract COVID-19 virus. Then, notably, the number nineteen (19) explicitly mentions between verses 29 and 30; reading "over it are nineteen (angels guarding)." Verse 31, on the other hand, describes COVID-19 as God's soldier traveling freely across the world; this particular piece of information may have meaning, if referred to the periodic table, where these two numbers represent respectively element copper $(\mathrm{Cu})$ and element Zinc (Zn).

5. Verses 32-34 provide an approximate microscopic image of the COVID-19 virus (it looks like a sun from which sparks are emitted and on which a dark moon-like shape is placed).

6. In Verses 48-55, the section reading (Like zebras fleeing a lion) constitutes an analogy to today's world imposed by COVID-19. Such analogy may bear meaning in that the lion, representing the king of all animals -for humans-, may represent of the crown of the virus. Besides, this Quranic scene of zebras fleeing a lion in horror resembles today's chaotic situation in many countries.
7. Verses 31-56 explain how to avoid this pandemic (medical prophylaxis).

In downplaying with the derivation context, there are two words "nuqir" and "naqoor" in the 8th verse of AlMuddaththir, derived from the root word "qaf ra nun" (ن) Q Q Q Q (ن) is generally understood to denote the endtime trumpet and thus the verse has been translated by Sahi International and others as, "And, when the trumpet is blown." Wiktionary.org mentions that the Proto-Semitic use of "qarana" denotes "horn" associated with the ancient Greek word khrónos (sounds like corona), means time or lifespan. Some commentators have also taken it as horn, as an instrument sounding far and wide, for instance by Abdul Majid Dariyabadi, who interpreted the verse as, "Then, when the horn sounds." The Arabic lexicons also take the word as denoting to a time span of hundred years or a century like the ancient Greeks, besides to other meanings. The word "qarna" also conveys such meanings in the Arabic language as yoke, coupling, conjugating, pod, peer, peek, etc. The Quranic word "qarnin" is taken as to mean generations. The plural of this word, 'quruna' (قُرُون) , have a strange phonetic similarity with the English word 'corona'. It may be found striking that the coronavirus exhibits most peculiarities expressed in the Arabic word "qarna" or its plural "quruna" [20].

One issue that needs to be understood here is that the given verse is futuristic in tone and not informing about something occurring by the time of its revelation, so much so that it has been generally taken as an end-time sign by most scholars. Suppose the word 'qarna' or its plural 'quruna' is applied in its meaning of a period, i.e., century or centuries. In that case, the appearance of quruna may be taken as an event taking place century after a century or during a particular century. The mention of the word ' 19 ' in verse 30 of the chapter makes it evident that this verse points to an event that will occur when the word "quruna" will be bonded with a '19' epithet.

It is evident from the above rendering that, apart from its classical message, Surah Muddaththir deals with an affliction termed as Saqar-19, an equivalent of the pandemic caused by COVID-19 since the last month of 2019, emerging from Wuhan in China. The context of this and Surah Qamar makes it explicit that the Saqar traditionally understood to be a fire of hell should be better interpreted as the burning scourge in the mundane 
world, which shrouds humankind as a consequence of capitalist injustice. Saqar-19 will gravely affect the global economic system, mainly dominated today by the American hegemony. Chapter 74 of the Quran mentions Saqar-19 as a global and universal affliction with all its manifestations as described in the relevant verses. It is a course-correcting measure of nature and may be considered a meta-fluctuation in human history, which is hitting hard on the greedy leadership. It may be taken as a reminder to humankind for amending its attitude towards the divine signs and pursuing the ethical aspect of economic justice in a world marred with wars and violence, here and there, to grab natural resources and control economies.

\section{SURAH MARYAM (MARY) AND COVID-} 19

In the researcher's view, the COVID-19 pandemic also can be shown obviously through the signs in the Surah Maryam as the 19thSurah with 98 verses. The unique aspects of this Surah are nine stories mentioned; eight prophets (Zakaria, Yahya, Isa, Ibrahim, Musa, Harun, Ismail, and Idris) and Isa's mother (Maryam). This number refers to the number of 9 in COVID-19, while the number one refers to the Qawlul Haqq (a statement of truth) in the 34 th verse is Isa peace be upon him.

The Surah Maryam also points out artistic features with the soft rhythm and one pattern marked at the end of each verse, such as khafiyya, syaqiyya, waliyya, rodhiyya, sawiyya, 'asyiyya, shobiyya, bukiyya, and others. It is so touching to call the Most Merciful with a call in secret, mildness, falling prostrate and weeping, and to glorify Allah's Praises in the morning and the afternoon. The self-isolation strategy is shown in the Maryam story (22nd verse) and Ibrahim (48th verse). It also indicates that the coronavirus has moved from a surface of the human body or clothing to another in secret; nobody sees its spreading directly and know when the COVID-19 will end, it can move freely in two times (morning and night), and it swallows the victims slowly and likewise the infected person can recover gradually by self-isolation and prophetic treatment (Surah Maryam: 3-58). Hence, the best treatment or strategy to deal with this virus is to be constant and patient in His worship and call upon the Lord, falling prostrate and weeping in secret as mentioned in the 58th and 65 th verses of Maryam.
The last one of the linkages between the corona and this Surah is the word قرن (qarn) mentioned twice in the 74th verse and the last verse (98th)and it means the old generation that Allah has destroyed. In verse 74, they mean better people in wealth, possessions, looks and appearance than these present people. While the 98th verse stated the word, Qarn means from the nations that disbelieve in Allah's signs and reject His Messengers [21].

Coronavirus disease is one of the signs that Allah test to this generation, either who bestowed with the best dwellings and splendid bounties of wealth or who has the poverty life and limitedness, with the deaths and extension (circumstances) until when they will come to know who is worst in position, and who is weaker in forces, who is the Muttaqin and who is the Mujrimin (85th and 86th verses.

In a nutshell, the days of COVID-19 are from Allah's days that He gives to men by turns to test (or purify) the believers (from the sins) and destroy the disbelievers. (Ali Imran: 140-141).

As the essential prevention of corona virus, cleanliness is a significant part of Islam's high standards and values. Health authorities' preventive measure to reduce the spread of ongoing pandemic COVID-19 is similar to those cleanliness guidelines that Islam provided years ago. In the 10th century, to prevent human-to-human contamination, an Islamic scholar of Medicine, Ibn Sina, used a isolating people for 40 days to limit the spread of contagious diseases. This situation is translated to "quarantine". Different countries have now adapted this practice during this coronavirus disease outbreak. Islam has a tradition of following science. Muslim physicians' and scientists' contribution to biological science were most significant greatest between the 8 th and the 13 th centuries. This period was referred toas the 'Islamic Golden Age'. Islam significantly emphasizes persersonal hygiene and food hygiene, and faith can play a significant part in global efforts topromote hand hygiene, which in the current situation is fundamental in reducing the impactof the corona virus outbreak.

Ablution for a Muslim is an excellent practice for limiting the spread of germs. As stated in the Holy Qur'an (5:6), ablution includes washing all exposed parts of the body including hands, feet, face, mouth and nose. A Muslim will does them five times a day. It is consistent with the WHO's first guideline for all society 
members to wash hands regularly and entirely with soap and warm water [22].

In moral crisis issue as a fundamental aspect to build a pious and hygiene generation, so the turn to Allah in repentance will lead to purifying the heart and soul as the primary qualification to be real excellence and hygiene generation as Allah mentioned clearly in Holy Qur'an: "And they ask you about menstruation. Say, "It is harmful, so keep away from wives during menstruation. And do not approach them until they are pure. And when they have purified themselves, then come to them from where Allah has ordained for you. Indeed, Allah loves those who are constantly repentant and loves those who purify themselves." (Al- Baqarah: 222).

\section{CONCLUSION}

The verses of Surah (chapter of the Quran) AlMuddaththir (The cloaked one) and Surah Maryam seem to bear valuable information (signs) on the ongoing pandemic, in that many commonalities between the interpretations of theverses of the mentioned Surah and many facts about COVID-19 may be noticed and noted. This interpretation is not solely presented to prove the Holy Quran's truth as the book of signs, but to disclose the phenomena through the beautiful verses expressions and harmony structures. An important lesson from the phenomenon of COVID-19 is a belief in the Divine Preordainment that Allah knows what happens and what shall happen; Allah knows the conditions, deeds, life spans, and provisions of His slaves. He created man to worship Him and made that clear to him. Allah also commands man to obey Him, forbids him from disobeying Him, and makes that clear to them. He gives them the power carry out His commandments and getting reward, and by which they could perpetrate acts of disobedience, and get punished. All embodiments are recorded in the artistic imageries and impressive Qur'anic stories.

\section{REFERENCES}

[1] WHO. (2020). https://www.who.int/healthtopics/coronavirus\#tab=tab_1

[2] World Health Organization. (2000). World Health Organization. https://covid19.who.int/

[3] WHO. (2020). Novel Corona virus - China.

[4] Organization, W. H. (2020). Critical preparedness, readiness and response actions for COVID-19. June, 1-10. file:///C:/Users/hp/Downloads/WHOCOVID-19-Community_Actions-2020.4-eng.pdf
[5] Wu, K. J. (2020). No Title. National Geographic Society.

[6] Koonin, E. V, Senkevich, T. G., \& Dolja, V. V. (2006). The ancient Virus World and evolution of cells. Biology Direct, 27, 1-27. https://doi.org/10.1186/1745-6150-1-29

[7] Lawrence, C. M., Menon, S., Eilers, B. J., Bothner, B., Khayat, R., Douglas, T., \& Young, M. J. (2009). Structural and Functional Studies of Archaeal Viruses *. Journal of Biological Chemistry, 284(19), 12599-12603. https://doi.org/10.1074/jbc.R800078200

[8] Robilotti, E., Deresinski, S., \& Pinsky, B. A. (2015). Norovirus. Clinical Microbiology Reviews, Journal of ASM, 28(1), 134-164. https://doi.org/10.1128/CMR.00075-14

[9] Oxford University Press. (2015). Oxford University Press.

[10] Iyer LM, Balaji S, Koonin EV, A. L. (2006). Evolutionary genomics of nucleo-cytoplasmic large DNA viruses. Elsevier, 117(1), 156-184. https://doi.org/https://doi.org/10.1016/j.virusres.20 06.01.009

[11] Sanjua, R., Nebot, M. R., Chirico, N., Mansky, L. M., \& Belshaw, R. (2010). Viral Mutation Rates. Journal of Virology, 84(19), 9733-9748. https://doi.org/10.1128/JVI.00694-10

[12] University, J. H. (2020). COVID-19 Dashboard by the Center for Systems Science and Engineering (CSSE).

[13] Disease, C. (2020). Interim Clinical Guidance for Management of Patients with Confirmed Coronavirus Disease (COVID-19) Clinical Presentation Incubation period Asymptomatic and Pre-Symptomatic Infection Asymptomatic and Pre-Symptomatic Transmission Clinical Course Illness Severity. 2019, 4-9.

[14] The Economist. (2020).

[15] Lederer, E. M. (2020). UN food agency chief: World on the brink of "a hunger pandemic." https://abcnews.go.com/US/wireStory/foodagency-chief-world-brink-hunger-pandemic70269400

[16] UNESCO. (2020). 290 million students out of school due to COVID-19: UNESCO releases first global numbers and mobilizes response.

[17] Burton N. (2020). The corona virus exposes the history of racism and "cleanliness."

[18] Bernard Wood. (2011). Human Evolution. Oxford University Press 
[19] Khenenou, T., Laabed, S., Laabed, O., \& Daniel, V. (2020). Did the Quran Mention COVID-19 Pandemic? Medical and Sanitary Prophylaxis of this Disease. Journal of Medical Biomedical and Applied Sciences, 8(4), 375-377. https://doi.org/10.15520/jmbas.v8i4.222

[20] Muslim Mirror. (2020). Probable mention of a COVID-19 like pandemic in the Quran.

[21] Ibn Kathīr. (2000). Tafsir Ibn Kathīr (Abridged by a group of scholars) (S. al- Mubarakpuri (Ed.); 1st ed.). Darussalam.

[22] Maxwell, D. N., Perl, T. M., \& Cutrell, J. B. (2020). "The Art of War" in the Era of Coronavirus Disease 2019 (COVID-19). Clinical Infectious Diseases, Editorial Commentary, 2019(XXXX),

2019-2021.

https://doi.org/10.1093/cid/ciaa229 